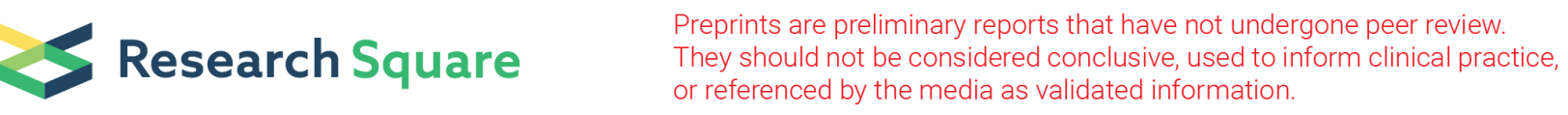

\title{
Environmental coastal management for groundwater resources using different aquifer bed slopes considering sea level rise risk
}

Ismail Abd-Elaty ( $\square$ eng_abdelaty2006@yahoo.com )

Zagazig University Faculty of Engineering

Maurizio Polemio

IRPI-CNR: Istituto di Ricerca per la Protezione Idrogeologica Consiglio Nazionale delle Ricerche

\section{Research Article}

Keywords: Coastal, aquifers, management, SLR, SEAWAT, bed slopes, Gaza

Posted Date: February 17th, 2022

DOI: https://doi.org/10.21203/rs.3.rs-1307616/v1

License: (c) (1) This work is licensed under a Creative Commons Attribution 4.0 International License.

Read Full License 


\section{Abstract}

Todays, coastal groundwater management is a challenging research topic due the relevance of these water resources and the huge suffered risks due to the global change in the coastal areas. The geometrical features of coastal aquifers play a control role on salt water intrusion (SWI). Seawater level rise (SLR), groundwater over pumping and aquifer recharge reduction promoting SWI. All these key factors are considered are considered with two different numerical approaches defining schematic management criteria. The former approach adopts the well-known Henry's problem; the latter is based on the real study case of the Gaza aquifer (Palestine). Different aquifer bed slopes, hydraulic and physical methods, including physical subsurface barriers, earth fill, check dam, abstraction, and natural or artificial recharge are considered together with SLR, recharge reduction, and over pumping. The different scenarios are compared in terms of position of saltwater intrusion interface, measured as distance from the coastline at the aquifer bottom using the numerical code SEAWAT. Useful comparing tables and considerations are defined with the purpose to guide the preliminary selections of new management solutions for reducing the effect of the global change on coastal groundwater resources around the coastal world. The land side bed slope cases show more SWI than sea side and horizontal bed slopes. Cut-off walls and check dams are effective technique to manage SWI in horizontal bed aquifers slopes more than other slopes, also the subsurface dams, earth fill and recharge of freshwater are good methods to control the SWI in land bed slopes while abstraction of brackish water and combine of freshwater recharge with brackish water abstraction are better to mitigate of SWI in sea side slopes.

\section{Introduction}

The influence of climate change (CC) on the availability of high quality water resources is now widely recognized over the worlds (McDonald et al, 2011). In particular, the investigation, management and mitigation of saline water intrusion (SWI) in coastal regions are a recurrent environmental problem and affected by CC (Abd-Elaty et al, 2019a; Polemio \& Zuffianò, 2020). Around $70 \%$ of the world's population lives in coastal areas where very high population density is observed; this percentage shows widespread increasing trend causing the increase of water demand (McDonald et al, 2011; Wada er al, 2016, AbdElaty et al, 2021a) ). Combination of increase demand and CC exposes coastal groundwater to increasing salinization risks for SWI, especially in water scarce regions (Polemio \& Zuffianò, 2020). SWI can worst due to human activities and natural process by reduction in groundwater recharge, over pumping, tidal effects, ocean and seismic waves, dispersion effects, and CC including sea level rise (SLR) (Bear et al., 1999). SWI managment becomes necessary in all these cases for the coastal groundwater protection from salinization (Abd-Elaty et al, 2021b).

Around $95 \%$ of the world's coastal areas will be severely affected by SLR by 2100 , increasing the risk of flooding and SWI (Agren and Svensson, 2017). The rise of global mean sea level is expected continues into the future; the most recent best assessment (IPCC, 2021) is $0.28-0.55 \mathrm{~cm}$ by 2100 while it was 18 to $58 \mathrm{~cm}$ in 2007 (IPCC, 2007), with a rate of rise 8 to $16 \mathrm{~mm} /$ year during 2081 to 2100 (IPCC, 2014). IPCC 
(2007and 2014) indicated that the rainfall has increased in most mid-latitudes and high latitudes, while it has decreased in many mid-latitudes and subtropical arid regions in the 20th century.

The use of numerical modeling supporting the design and selection of management criteria is a reliable choice in the case of groundwater at salinization risk (Polemio \& Zuffianò, 2020). Abd-Elhamid et al., (2016) investigated the effect of different SLR scenarios on the coastal region of Nile delta, Egypt using SEAWAT. The results showed that the groundwater salinity have a significant effect by SLR.

Mahmoodzadeh and Karamouz (2019) indicated that the storm surge has a short-term SWI influence while the SLR has a relevant long-term SWI influence on fresh groundwater of a fully heterogenic coastal aquifer using the code SUTRA. Optimization of freshwater abstraction and management of salinization risks are the main management challenges for water supply decision makers (Bear and Cheng, 1999). Different techniques have been applied and developed to SWI management (Todd, 1974; Polemio \& Zuffianò, 2020). Hydraulic Barrier (HB) methods use injection by wells or infiltration by ponds of lowquality fresh water or abstraction of saltwater to permit the safe discharge of fresh groundwater of high quality. Artificial recharge technique is man's planned operation used to increase the fresh groundwater heads (Bear, 1979). This method is applied to the aquifer through the infiltration by surface ponds or recharge wells (Roger, 2010). Abd-Elhamid and Javadi (2008a) applied the abstraction and desalination of brackish water, and recharge to control SWI in coastal aquifers. Abd-Elhamid and Abd-Elaty (2017) tested an effective management method using SEAWAT code, which consists in the treatment of wastewater to be used for artificial recharge after abstracted and desalination of brackish water and. Abd-Elaty et al, (2020a) used a numerical method for the Gaza Strip aquifer (Palestine) using different methods and scenarios to control SWI. The results indicated that the recharge of treated waste water could mitigate the SWI compare with the other method using the abstraction of brackish water, also the combine of the two methods is the best choice. Abd-Elaty et al, (2021c) simulated and management of SWI in Nile delta using combination of recharge and abstraction well system. The results showed that this technique was effective to mitigate the contamination of groundwater in coastal regions.

Physical Subsurface Barrier (PSB) methods use cut-off walls (CWs) or subsurface dams (SDs), also sheet piling and earth fill. The barrier creates a discontinuity between the coastal brackish portion of the aquifer and the inland portion, where fresh groundwater can be safely discharged (Javadi et al., 2015). Abd-Elaty Et al. (2019b) highlighted that the PSB technique is used to mitigate the SWI in coastal aquifers; also the cut-off walls are effective to control the SWI more than subsurface dams. Roger et al., (2009) investigated the dynamics of residual saltwater by construction of cut-off walls. Abdoulhalik et al. (2017) applied the mix of PSB by a semi-permeable subsurface dam and an impermeable cut-off wall, the results showed that mixing PSB is effective to control of SWI more than the single methods. Abd-Elaty Et al. (2019b) simulated PSB systems efficiency to control SWI due to SLR and aquifer recharge reduction. The simulation showed that PSB is effective to manage in coastal aquifers salinity.

Land reclamation in coastal zones is usually occurs by extension of the shore line towards the sea side using the artificial filling of appropriate soil. The natural aquifer recharge by precipitation takes place over the reclaimed new land. Guo and Jiao (2007 and 2009) evaluated with simple calculations the effect of 
the land fill reclamation on the groundwater heads and SWI in coastal areas. The results indicated a water table rise on old land and the shift of the salt -fresh water interface. Abd-Elhamid et al, (2020) developed a numerical study usin SEAWAT code to investigate the effect of using fill width on management of SWI in coastal aquifers considering of sea level rise. Different earth fill solutions were compared for control SWI with different SLR. The authors showed the advantages of this solution.

In this current study the SEAWAT is used to provide a better understanding and a quantitative assessment of different management solutions using two approaches. The former approach adopts the well-known Henry's problem; the latter is based on the real study case of the Gaza aquifer (Palestine). On these bases, advantages of each solution are discussed.

\section{Materials And Methods}

The general characteristics, hypotheses, main data, and boundary conditions concerning the numerical code, the Henry's problem and the selected real study area of coastal aquifer the bed slope are described.

\subsection{Variable density Model}

The finite difference model of SEAWAT 2000 (version 4) was applied and simulated the SWI in the current coastal aquifers. This code is couple miscible variable-density process of MODFLOW (Harbaugh, et al., 2000) and MT3DMS (Zheng and Wang, 1999) into a single program.

The VDF process solves the following variable density groundwater flow equation (Guo and Langevin, 2002):

$$
\nabla\left[\rho * \frac{\mu_{o}}{\mu} * K_{o}\left(\nabla * h_{0}+\frac{\rho-\rho_{f}}{\rho_{f}} * \nabla Z\right)\right]=\rho * S_{, S, 0}\left(\frac{\partial h_{O}}{\partial t}\right)+\theta *\left(\frac{\partial \rho}{\partial C}\right)\left(\frac{\partial C}{\partial t}\right)-\rho_{S} * q s
$$

The IMT process solves the following solute transport equation (Zheng and Wang, 1999):

$$
\frac{\partial\left(\theta C^{k}\right)}{\partial t}=\frac{\partial}{\partial x_{i}}\left(\theta D_{i j} \frac{\partial C^{k}}{\partial x_{j}}\right)-\frac{\partial}{\partial x}\left(\theta v_{i} C^{k}\right)+q_{s} C_{k}^{s}+\sum R_{n}
$$

where: $\rho$ is the density of saline water $\left[\mathrm{ML}^{-3}\right] ; \mu_{\mathrm{o}}$ is the dynamic viscosity of freshwater $\left[\mathrm{ML}^{-1} \mathrm{~T}^{-1}\right] ; \mu$ is the dynamic viscosity of saline groundwater $\left[\mathrm{ML}^{-1} \mathrm{~T}^{-1}\right] ; \mathrm{K}_{0}$ is the hydraulic conductivity tensor of material saturated with the reference fluid $\left[L T^{-1}\right] ; h_{0}$ is the hydraulic head $[L] ; \rho_{0}$ is the fluid density $\left[\mathrm{ML}^{-3}\right]$ at the reference concentration and temperature; $S_{s, 0}$ is the specific storage $\left[L^{-1}\right]$, $t$ is time $[T] ; \theta$ is porosity [-]; $\mathrm{C}$ is salt concentration $\left[\mathrm{ML}^{-3}\right] ; \mathrm{q}_{\mathrm{s}}^{\prime}$ is a source or sink of fluid with a density of $\rho_{\mathrm{s}}\left[\mathrm{T}^{-1}\right], \mathrm{C}^{\mathrm{k}}$ is dissolved 
concentration of species $\left[\mathrm{ML}^{-3}\right]$; Dij is the hydrodynamic dispersion tensor $\left[\mathrm{L}^{2} \mathrm{~T}^{-1}\right]$; $v_{i}$ is seepage or linear pore water velocity $\left[\mathrm{LT}^{-1}\right] ; \mathrm{C}_{\mathrm{s}}{ }^{\mathrm{k}}$ is the concentration of the source or sink flux for species $k\left[\mathrm{ML}^{-3}\right] ; \Sigma \mathrm{R}_{\mathrm{n}}$ is chemical reaction term $\left[\mathrm{ML}^{-3} \mathrm{~T}^{-1}\right]$.

\subsection{Hypothetical Case Study of Henry's problem}

Known Henry's problem (Henry, 1964) is used in the current simulation with domain of $2 \mathrm{~m}$ in horizontal (X-direction) to $1 \mathrm{~m}$ in vertical (Z-direction) with width of $0.10 \mathrm{~m}$ (Y-direction). The model was subdivided into 4 row, 80 columns and 40 layers. The flow and contamination boundary conditions of this problem were assigned by hydrostatic saline water pressure at the sea side of the model (right side) which represented the seaside by density $\left(\rho_{\mathrm{s}}\right)$ of sea or saline water, equal to $1025 \mathrm{kgm}^{-3}$, at a constant salt concentration $\left(C_{S}\right)$ of $35 \mathrm{kgm}^{-3}$. The aquifer side (left side), which represents the inland boundary where fresh groundwater is observed, corresponds to a recharge well with a constant inflow rate $\left(Q_{\text {in or }} Q_{f}\right)$ of $0.5702 \mathrm{~m}^{3}$ day $^{-1}$ at constant salt concentration $\left(C_{F}\right)$ by zero $\mathrm{kgm}^{-3}$. The top and bottom boundaries of the model are assumed to be no-flow boundaries (Figure.1a). The hydraulic parameters and solution methods for Henry's problem is presented in Table.1.

Table 1

Boundary conditions, hydraulic parameters and solution method for the Henry's problem

\begin{tabular}{|llll|}
\hline Hydraulic Parameters & Value & Dimension \\
\hline Porosity $(\mathrm{n})$ & 0.30 & - \\
\hline Freshwater density $\left(\rho_{\mathrm{f}}\right)$ & 1000 & $\mathrm{Kg} \mathrm{m}^{-3}$ \\
\hline Saltwater density $\left(\rho_{\mathrm{s}}\right)$ & 1025 & $\mathrm{Kg} \mathrm{m}^{-3}$ \\
\hline Specific storage & 0 & $\mathrm{~m}^{-1}$ \\
\hline Longitudinal dispersivity $\left(\mathrm{a}_{\mathrm{L}}\right)$ & 0 & $\mathrm{~m}$ \\
\hline Transverse dispersivity $\left(\mathrm{a}_{\mathrm{T}}\right)$ & 0 & $\mathrm{~m}$ \\
\hline Molecular diffusion coefficient(D*) & 1.6295 & $\mathrm{~m}^{2}$ day $^{-1}$ \\
\hline Vertical and Horizontal Hydraulic conductivity $(\mathrm{k})$ (Isotropic) & 864 & $\mathrm{~m} \mathrm{day}^{-1}$ \\
\hline Model Solution Method & Value & Dimension \\
\hline Implicit finite-difference solver with the upstream-weighting & $(\mathrm{GCG})$ & - \\
\hline Number of column $(\Delta \mathrm{x}=2.50 \mathrm{~cm})$ & 80 & - \\
\hline Number of raw $(\Delta \mathrm{y}=2.50 \mathrm{~cm})$ & 40 & - \\
\hline Initial time step & 0.01 & day \\
\hline
\end{tabular}


The problem results were verified using the results from different methods and codes. Ghyben-Herzberg model is the first model for SWI presented by Ghyben (1889) and Herzberg (1901) based on sharp interface. Henry (1964) presented the first semi-analytical solution considering the effect of dispersion. The problem was successfully studies by Pinder and Cooper (1970), Frind (1982), Rastogi et al. (2004) and Fahs et al. (2018). Recently the numerical models were applied to the problem (Miao at al., 2019); Zhao at al., 2020; Abd-Elaty et al. 2021).

The seawater intrusion distance (SID) is usually represented by the 0.5 equi-concentration (isochlor) line and measured along the bottom boundary from the aquifer seaside (Figure 2). SID reached $64.50 \mathrm{~cm}$ in the case of SEAWAT. The results of Figure $1 \mathbf{b}$ show good agreement between SEAWAT and other codes by Henry (1964), Intera (1979), Voss and Souza (1987), Simpson and Clement (2004) and SVCHEM (2018).

\subsection{The real case study of the Gaza aquifer}

Figure $2 \mathbf{a}$ is showed the location map for the Gaza Strip (GS) which is selected as areal case study with a total area of $365 \mathrm{~km}^{2}$ and a coastline length of $45 \mathrm{~km}$ along the Mediterranean Sea, the area width ranges from 6 at the north to $12 \mathrm{~km}$ at the south, the average width of the study area of $9 \mathrm{~km}$ (Abu Heen and Muhsen, 2016). GS is the most highly populated areas in the world (PCBS, 2000), where the annual population growth is approximately $2.9 \%$ (PCBS, 2014d) with density reached about 4822 capitakm $^{-2}$ in 2015 (PCBS, 2015).

Two formations can be distinguished in the area. The Tertiary "Saqiya formation" is located below of the GS aquifer and constitutes the aquifer bottom. It is composed by impervious clay shade rocks with thickness ranging from 400 to $1000 \mathrm{~m}$. The Quaternary deposits, covering the Saqiya formation, constitute the Gaza aquifer, with thickness about equal to $160 \mathrm{~m}$. These deposits include loose sand dunes (Holocene) and the Kurkar group (Pleistocene). The top of the Pleistocene deposits is covered by Holocene deposits with thickness of $25 \mathrm{~m}$; the average thickness of the Kurkar Group sequence reaches from 200 to $120 \mathrm{~m}$ in the south and the north respectively (Figure 2b) (Abu Heen and Muhsen, 2016).

The climate of GS is semi-arid where the average precipitation ranges between 200 to 400 mmyear $^{-1}$ (PWA, 2001, 2013), and the evaporation rate is about $1400 \mathrm{~mm}^{\text {year }}{ }^{-1}$ (SWIMED, 2002).

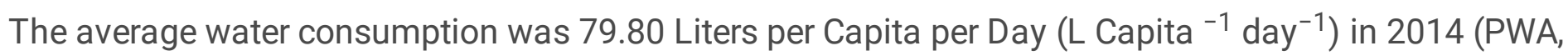
2015). The estimated domestic water was $88.47 \mathrm{MCM} \mathrm{yr}^{-1}$ about $96 \%$ from local water resources and $4 \%$ was purchased from Mekorot (Israel) (PWA, 2015), while agriculture water was about 95.3 million cubic meters per year ( $\mathrm{MCM} \mathrm{yr}^{-1}$ ) (PWA 2014). The amount of irrigation returns flow was estimated to be $20 \%$ of the total pumping (Melloul and Collin, 1994) or between 22 to $24 \%$ of the total irrigation water (Ghabayen and Salha,2013).

The aquifer flow by recharge was estimated to range between 100 to $120 \mathrm{MCM} \mathrm{yr}^{-1}$ from rainfall (main source), artificial recharge ponds, agriculture return flow and wastewater leakage (PWA 2013) (Abualtayef 
et al., 2017). The lateral inflow to the study area was estimated between 15 to $30 \mathrm{MCM} \mathrm{yr}^{-1}$ (Metcalf and Eddy, 2009). The overall water supplies losses was estimated by $45 \%$ (35\% by physical losses and $10 \%$ by unregistered connections) (PWA, 2013).

Desalination appears to be the only viable alternative to meeting the Gaza Strip's drinking water needs for the Coastal Urban Water Plan and the Palestinian Water Authority (PWA). The water supply by desalination was about $6 \mathrm{MCMyr}^{-1}$ (PWA, 2015). Around 95\% of drinking water purposes in GS depend on the desalination from small brackish water plants and home filters (Abu-Amr and Mayla, 2010) in addition to 10 MCM received from Mekorot water company (Shatat et al., 2018). For the long-terms, the volumes of desalinated flows were estimated by Technical Engineering Consulting Company (TECC) in GS to rise and expected by 10.57, 13, 49.13, 71,96 and 129,74 MCM by 2012, 2015, 2020 and 2035 (PWA, 2011).

Around 70 to $80 \%$ of the domestic wastewater generated in the Gaza Strip is discharged without treatment into the environment (Baalousha, 2008), in additional the total volume produced by wastewater plants is about $41 \mathrm{MCM} \mathrm{yr}^{-1}$ in which about $8 \mathrm{MCM} \mathrm{yr}^{-1}$ was treated and $33 \mathrm{MCM} \mathrm{yr}^{-1}$ disposed to the Mediterranean Sea (PWA, 2012). In 2015, this volume was estimated to 48.54 MCM (ARIJ, 2015c; PCBS, 2013c, 2015c).

Groundwater is the main water supply in GS by $95 \%$, this water is contaminate by SWI (Qahman and Larabi 2006). For the natural conditions, the fresh groundwater flow in GS is from east to west, towards the Mediterranean Sea (Mercado, 1968). The groundwater deficit was between 40 to $60 \mathrm{MCM} \mathrm{yr}^{-1}$ for increasing the abstraction (PWA 2013) and Over $96.4 \%$ of the Gaza coastal aquifer (GCA) pumping excess accepted standards (PWA, 2015) while the sustainable yield of Gaza coastal aquifer (GCA) is only $55 \mathrm{MCM} \mathrm{yr}^{-1}$ (PWA, 2011). Overall abstraction has increased continuously over the past decade from 136 MCM in 2000 to 174 MCM in 2010 (PWA, 2010a). Sarsak (2011), Sarsak and Almasri (2013) Vand Abualtayef et al. (2017) were esimulated the GCA using SEAWAT code for the current situation and the future scenarios, the results showed that the aquifer is sensitive to SLR and the treated wastewater, desalination and storm water infiltration are the future resources for SWI management in GS.

Table 2 summarises the input parameters used for the GCA modelling (Sirhan and Koch, 2013). The GCA transmissivity ranges between 700 to $5,000 \mathrm{~m}^{2}$ day $^{-1}$ with hydraulic conductivity $\mathrm{K}_{\mathrm{x}}$ and $\mathrm{K}_{\mathrm{y}}$ between 20 to $80 \mathrm{~m} /$ day. The aquifer effective porosity is $35 \%$, the specific yield ranges between 0.15 to 0.30 while the specific storage was $10^{-4} \mathrm{~m}^{-1}$ (PWA, 2000b). The longitudinal dispersivity $\left(a_{\mathrm{L}}\right)$ and transverse dispersivity $\left(a_{T}\right)$ were $50 \mathrm{~m}$ and $0.10 \mathrm{~m}$ respectively (Qahman, 2004). 
Table 2

Hydraulic parameters and boundary conditions for Gaza aquifer modelling

\begin{tabular}{|c|c|c|c|}
\hline Parameters & Confined aquifer & Unconfined aquifer & Unit \\
\hline Horizontal hydraulic conductivity $\left(\mathrm{K}_{\mathrm{h}}\right)$ & 0.20 & 34 & $m$ day $^{-1}$ \\
\hline Vertical hydraulic conductivity $\left(\mathrm{K}_{\mathrm{v}}\right)$ & 0.02 & 3.40 & $m$ day $^{-1}$ \\
\hline Effective Porosity $\left(n_{e}\right)$ & 0.30 & 0.25 & - \\
\hline Total Porosity $\left(\mathrm{n}_{\mathrm{T}}\right)$ & 0.45 & 0.35 & - \\
\hline Freshwater density $\left(\rho_{f}\right)$ & 1000 & 1000 & $\mathrm{Kg} \mathrm{m}^{-3}$ \\
\hline Saltwater density $\left(\rho_{s}\right)$ & 1025 & 1025 & $\mathrm{Kg} \mathrm{m}^{-3}$ \\
\hline Specific Storage & $10^{-5}$ & $10^{-4}$ & $\mathrm{~m}^{-1}$ \\
\hline Longitudinal dispersivity $\left(a_{\perp}\right)$ & 50 & 12 & $\mathrm{~m}$ \\
\hline Transverse dispersivity $\left(a_{T}\right)$ & 5 & 1.20 & $\mathrm{~m}$ \\
\hline Molecular diffusion coefficient(D*) & 0.0001 & 0.0001 & $\mathrm{~m}^{2}$ day $^{-1}$ \\
\hline Boundary Condition & Value & & Unit \\
\hline Lateral freshwater flux $\left(q_{i n}\right)$ & 10 & & $m^{3}$ day $^{1} m^{-1}$ \\
\hline Well abstraction rates & 20.75 & & $m^{3}$ day $^{1} m^{-1}$ \\
\hline Vertical recharge and return flow & 416.50 & & mmyear $^{-1}$ \\
\hline Saltwater head $\left(h_{s}\right)(0 \leq x \leq 1400 m)$ & zero & & $\mathrm{m}$ \\
\hline Sea side concentration (C) & 35000 & & $\mathrm{mg} \mathrm{L}^{-1}$ \\
\hline Land side concentration (C) & 1000 & & $\mathrm{mg} \mathrm{L}^{-1}$ \\
\hline
\end{tabular}

The SEAWAT model of GCA uses 180 columns, one row and 10 layers for active cells. The model cross section is presented in in Figure 3a: it is $9000 \mathrm{~m}$ in length in $\mathrm{x}$-direction; topography range between +58 to $-180 \mathrm{~m}$ above mean sea (MSL). The hydrostatic pressure is assigned at sea side to represent the saline water head while the constant flow on the inland side is assigned with freshwater using well modules in order to represent the freshwater recharge (Figure 3b). A constant concentration of $3500 \mathrm{ppm}$ is fixed at seaside while the landside a value of zero ppm is applied (Figure 3c).

Figure $3 \mathbf{d}$ is presented the distribution of salinity by Total dissolved solids (TDS) in the GCA for the current situation (base case). The initial time of 0.001 day and time step of 200 day. The calibration process is done using the method of trial and errors between the calculated values by SEAWAT (current 
model) and the other values published by previous studies. The current results are compared with Sarsak (2011) and Abd-elaty et al. (2020a). The results showed a good match between the other two models. The 0.5 isochlor reached a distance of $3177 \mathrm{~m}$ from the sea shore line in the horizontal case. The calibrated model is used in validation process to simulate different scenarios to control SWI intrusion. The total salt mass reached 5,718,820 kg.

\subsection{Proposed scenarios}

The study simulated three cases of bed slopes: seaside slope, with slope by 10 (horizontal):1(vertical); horizontal bed and landside slope, by 10:1 as (Figure 4a, c and e). SID reached 59.50, 64.50 and $65.125 \mathrm{~cm}$ respectively, as presented in Figure $4 \mathrm{~b}, \mathrm{~d}$ and $\mathrm{f}$. The results showed that the bed slope of aquifer has a great effect of saltwater intrusion, in which the land side slope has more intrusion than horizontal and seaside slopes.

\section{Results And Discussions}

The model was carried out to simulate the effect of SLR and reduction in fresh groundwater recharge, also the management scenarios were applied for physical subsurface barriers, land reclamation SWI, abstraction and recharge, and check dams methods for Henry's problem and the real case of Gaza coastal aquifer.

\subsection{Effect of SLR and recharge reduction on SWI for Henry's problem}

Tide log data showed sea level increases of $1 \mathrm{~mm}$ per year over a period of 2 centuries before 1990, while the satellite and tide log data showed an increase of $3.2 \mathrm{~mm}$ per year after 1990(Church and Clark, 2013). The trends of SLR and decrease the flow to the aquifer are due to CC in large world regions, including the Mediterranean Sea (IPCC, 2021).

Figure 5 shows the results in the case of SLR and recharge reduction for the three cases of bed slopes of seaside, horizontal and landside. The SEAWAT is used for the hypothetical case of Henry's problem to simulate the combine of SLR and reduction in aquifer recharge for the tree cases of bed slopes with the reference to the hypothetical steady or initial natural conditions, considering a sea level head by $100 \mathrm{~cm}$ at the ocean side and a constant recharge to the aquifer by rate of (Qin) $0.5702 \mathrm{~m}^{3}$ day $^{-1} \mathrm{~m}^{-1}$ at the land side. The expected saline water rise was simulated by increasing sea water level at the seaside by $3,6,9$, 12 and $15 \mathrm{~cm}$ while the freshwater recharge was decreased by $5,10,15,20$ and $25 \%$. The Salt rise or repulsion (\%) in aquifer is calculated by this

\section{$\%$ Salt rise or repulsion $=\left(\mathrm{C}_{0}-\mathrm{C}\right) / \mathrm{C}_{0}$}

Where $\mathrm{C}_{0}$ is the initial aquifer salt concentration and $\mathrm{C}$ is the aquifer salt concentration at the proposed scenario, the negative sign (-) means that the salinity in aquifer is increases while the positive sign (+) 
means that the salinity is decreased.SID resulted $65,72.50,77.375,82.625$ and $90 \mathrm{~cm}$ compared with $59.50 \mathrm{~cm}$ at base case for seaside slope. The salinity was increased to reached $-14.45,-30.34,-48.09$, -67.84 and $-89.50 \%$. The horizontal slope is showed that the intrusion is reached $70.125,77.50,84.25$, 92.125 and $100 \mathrm{~cm}$ compare with $64.50 \mathrm{~cm}$ at base case, the salinity increase is reached $-15.03,-31.62$, $-50.18,-70.76$ and $-93 \%$. Moreover, the intrusion is reached $72.50,80,92.50,97.25$ and $105.25 \mathrm{~cm}$ compare with $65.125 \mathrm{~cm}$ at base case with increase in salinity reached $-16.07,-33.87,-66.13,-75.45$ and $-98.46 \%$. The results showed that SLR has a negative impact on aquifer salinity and increase SWI and the landside slope increases the SWI more than horizontal and sea side bed slope where the average percentage of increasing SWI was $-57.99,-52.12$ and $-50.05 \%$.

\subsection{Management of SWI for Henry's problem}

Management of SWI is carried out using different hydraulic and physical methods including physical subsurface barriers, earth fill, abstraction, recharge and combination between abstraction and reached methods and check dam. The hypothetical of Henry's problem and the real case study of coastal Gaza aquifer were simulated at combine of SLR and reduction in recharge and over pumping.

\subsubsection{Effect of physical subsurface barriers}

The simulated solution was applied on the three types of bed slope using two physical subsurface barriers with the previous parameters and boundary conditions. The former is a cut-off wall and the latter is a subsurface dam.

Different scenarios were applied and analysing the SWI for different wall depths and dam heights by 15 , 30,45 and $60 \mathrm{~cm}$.

The results showed that SUI reached $85.25,75.125,62$ and $49.75 \mathrm{~cm}$ with reduction in salinity of +6.23 , $+19.38,+34.26$ and $+47.64 \%$ for cut-off wall. Based on subsurface dam results, SUl was $82.625,75,70.25$ and $69 \mathrm{~cm}$ with salinity reduction equal to $+3.56,+10.14,+13.43$ and $+14.38 \%$ (Table 3 ).

The horizontal slope results showed that SWI reached $92.25,79.50,67$ and $50 \mathrm{~cm}$ with salinity reduction of $+9.97,+24.79,+35.31$ and $+50.34 \%$, respectively, measured along the bed. The subsurface dam results showed that SWI reached $92.625,81.25,72.50$ and $70.50 \mathrm{~cm}$ with salinity reduction of $+3.44,+10.58$, +17.12 and $+18.66 \%$.

For landside slope SWI reached $100,87.75,71$ and $50.50 \mathrm{~cm}$ with salinity reduction of $+6.07,+19.58$, +36.27 and $+52.71 \%$. SUl reached $98.75,87.25,75.50$ and $70.125 \mathrm{~cm}$ with salinity reduction of +3.21 , $+10.58,+18.52$ and $+21.90 \%$ for subsurface dam.

The relation between the SWI lengths $(X T)$ and the physical barriers method for cutoff wall and subsurface dam for different bed slopes are presented in Figure $6 \mathrm{a}$ and $6 \mathrm{~b}$.

\subsubsection{Effect of land reclamation SWI}


The technique of earth fill is simulated by increasing the model width to $220 \mathrm{~cm}$ using $20 \mathrm{~cm}$ of fill with changing the fill permeability by $-70,-55,-40$ and $-25 \%$ to reach $734.40,604.80,345.60$ and $216 \mathrm{~m}$ per day for the three bed slopes. The 0.5 Isochlor is reached a distance of $67.625,62.50,57$ and $41.50 \mathrm{~cm}$ from the sea side with reduction in salinity reach $+3.39,+9.85,+16.67$ and $+33.78 \%$ respectively. The intrusion length of 0.5 equi-concentration line is reached $74.75,69.50,61.75$ and $47.50 \mathrm{~cm}$ respectively are measured along the bed with salinity reduction is reached $+6.83,+12.62,+21.18$ and $+34.96 \%$ for horizontal bed slope. Moreover the landside slope, the 0.5 Isochlor is reached $77.50,72.50,65$ and $50 \mathrm{~cm}$ measured along the bed with salinity reduction by $-8.78,+14.09,+22.13$ and $+35.43 \%$.

The relations between the intrusion length (XT) and the fill earth methods for different bed slopes are shown in Figure 6c.

\subsubsection{Effect of abstraction and recharge methods}

This technique used three cases to investigate the effect of the aquifer abstraction and recharge on SWI: (a) abstraction of saline groundwater, (b) recharge with waste water or storm water, and (c) combination of both. Different settings of aquifer bed slopes were also examined and assessing the SWI improvement in terms of SUI and salt repulsion. The recharge well was located at $1 \mathrm{~m}$ from shore line with depth $-0.40 \mathrm{~m}$ form the model top, while the abstraction well was simulated at $0.40 \mathrm{~m}$ from shore line with depth -0.85 from the surface of the hypothetical case with recharge and abstraction rates of $0.11404 \mathrm{~m}^{3}$ per day per meter. The intrusion of 0.5 isochlor for seaside slope reached $81.25,74.50,66.75$ and $60.25 \mathrm{~cm}$ with salinity reduction by $+14.38,+26.17,+35.92$ and $+44.04 \%$ with abstraction of saline groundwater.

The results of wastewater recharge showed that SUI is reached $85.75,80.25,77.75$ and $75 \mathrm{~cm}$ with reduction is reached $+3.05,+6.21,+9.26$ and $+12.02 \%$.

The combination of saline water abstraction and freshwater recharge showed that SWI reached 77.375, $66.50,58$ and $53.75 \mathrm{~cm}$ with reduction in salinity of $+17.51,+31.14,+41.24$ and $+48.33 \%$, respectively.

The results of abstraction showed SUI values of $90,80.75,73$ and $65.75 \mathrm{~cm}$ with salinity reduction of $+14.17,+26.11,+36.17$ and $+44.63 \%$ for horizontal slopes. The recharge results are indicated that the SWI is reached $97,92.75,89.50$ and $85 \mathrm{~cm}$ with salinity repulsion is reached $+2.69,+5.57,+8.45$ and $+11.19 \%$. Moreover for combine of abstraction and recharge, the intrusion is reached 86.75, 75.125, 67.125 and 61 $\mathrm{cm}$ with repulsion is reached $+17,+30.66,+41.12$ and $+48.75 \%$.

SWI results for landside slope and abstraction are $95,85,75.50$ and $68.25 \mathrm{~cm}$ with repulsion of +14.05 , $+26.17,+36.59$ and $+45.48 \%$ at seaside slope. The recharge results are $102.25,98.75,95$ and $92.25 \mathrm{~cm}$ with repulsion equal to $+2.44,+5.11,+7.85$ and $+10.53 \%$ while combining abstraction and recharge reached $92.25,80.25,71.25$ and $65 \mathrm{~cm}$ with repulsion of $+16.65,+30.42,+41.25$ and $+49.32 \%$, as presented in Figure 6d, 8e and $6 \mathrm{f}$.

\subsubsection{Effect of check dams}


This case represents the effect of check dams on SWI. The head of dam is changed by $17.50,18,18.50$ and $19 \mathrm{~cm}$. SUl reached $51.16,39.27,30.81$ and $24.56 \mathrm{~cm}$ respectively. The repulsion is $+21.39,+39.67$, +52.66 and $+62.27 \%$ for sea side slope. The results of horizontal slope are reached $83,67.625,55.75$ and $47.25 \mathrm{~cm}$ while the repulsion is reached $+22.73,+42.35,+55.99$ and $+65.77 \%$. For land side slope, SUI reached $67.38,52.38,39.24$ and $35.19 \mathrm{~cm}$ with repulsion is $+20.13,+37.92,+54.79$ and $+62.45 \% \mathrm{~m}$, as presented in Figure $6 \mathrm{~g}$.

The results showed that the average values for SWI repulsion were $26.88,30.09$, and $28.66 \%$ using cut-off wall and reached $+10.38,+12.45$ and $+13.55 \%$ using subsurface dam for the three aquifer bed slopes (sea side, horizontal and land side respectively) which indicate that the cut-off walls are more effective for horizontal bed slopes while the subsurface dam for land side slopes. The use of land fill is a good method in land side slopes where the SWI repulsion reached $+15.92,+18.90$, and $+20.11 \%$.

The use of hydraulic methods of freshwater recharge led to repulsion of $+30.13,+30.27$ and $+30.57 \%$ while using abstraction of brackish water to $+7.64,+6.97$ and $+6.48 \%$, moreover combination of freshwater recharge and brackish water abstraction led to $-34.55,-34.38$ and $-34.41 \%$. These results indicated that recharge methods are more effective in the case of land side bed slope while abstraction and combination are more effective in the case of sea side bed slope. The check dam led to SWI repulsion of $+44,+46.70$ and $+43.82 \%$ which indicates that check dams are effective in horizontal bed slopes.

\subsection{Effect of SLR and natural recharge reduction on SWI for the Gaza coastal aquifer}

The effects of SLR and recharge reduction on GCA were simulated changing boundary conditions and hydrogeological parameters. SLR consists of a change of saline water head equal to $23.60 \mathrm{~cm}$ by 2050 .

The natural recharge reduction was simulated with reduction of precipitation and lateral flow by $25 \%$. The practical effect of these hypothesis reduced the recharge contributions to 36.15 and $19.35 \mathrm{MCM} \mathrm{yr}^{-1}$ respect to 48.20 and $26.60 \mathrm{MCM} \mathrm{yr}^{-1}$ at base case.

The aquifer return flow by leakage from for domestic, agriculture and wastewater sectors should increase to reach $62.56,16$ and $21.89 \mathrm{MCM} \mathrm{yr}^{-1}$ for each sector, to be compared with $28.50,16$ and $9.98 \mathrm{MCM} \mathrm{yr}^{-1}$ respectively. This should be due to abstraction increase, which should be necessary to satisfy the increasing water demand. The total return flow should reach $100.45 \mathrm{MCM} \mathrm{yr}^{-1}$ compare with $54.48 \mathrm{MCM}$ $\mathrm{yr}^{-1}$ at base case.

The total of natural recharge and return flow could be considered equal to $136.60 \mathrm{MCM} \mathrm{yr}^{-1}$ compared with $102.68 \mathrm{MCM} \mathrm{yr}^{-1}$ at base case.

The groundwater abstraction should increase to reach $288.52 \mathrm{MCM} \mathrm{yr}^{-1}$, to be compared with $175 \mathrm{MCM}$ $\mathrm{yr}^{-1}$ at base case. 
Table 4 summaries the entire simulated modifications al 2050. The results of equi-concentration line 35000 ppm are shown in Figure 7, the intrusion length reached $6281 \mathrm{~m}$ from shore line measured at aquifer bottom and the salt mass is reached $1.04621 \times 10^{7} \mathrm{~kg}$.

Table 4

Different scenario for Gaza aquifer in 2050

\begin{tabular}{|c|c|c|c|}
\hline \multirow[t]{2}{*}{ Stage No. } & \multirow[t]{2}{*}{ Case } & \multicolumn{2}{|c|}{ Time (year) } \\
\hline & & 2010 & 2050 \\
\hline I & Seal level rise $(\mathrm{cm})$ & 0 & 23.60 \\
\hline \multirow[t]{8}{*}{ II } & 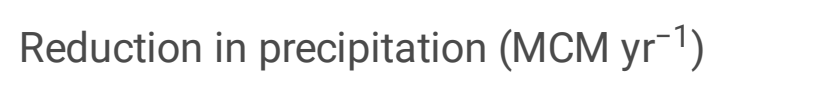 & 48.20 & 36.15 \\
\hline & Lateral flow & 26.60 & 19.35 \\
\hline & Wastewater quantity $\left(\mathrm{MCM} \mathrm{yr}^{-1}\right)$ & 49.88 & 109.47 \\
\hline & Domestic leakage (Return flow) (MCM yr ${ }^{-1}$ ) & 28.50 & 62.56 \\
\hline & Agriculture leakage $\left(\mathrm{MCM} \mathrm{yr}^{-1}\right)$ & 16 & 16 \\
\hline & Wastewater leakage (MCM yr $\left.{ }^{-1}\right)$ & 9.98 & 21.89 \\
\hline & Total leakage $\left(\mathrm{MCM} \mathrm{yr}^{-1}\right)$ & 54.48 & 100.45 \\
\hline & Total aquifer recharge $\left(\mathrm{MCM} \mathrm{yr}^{-1}\right)$ & 102.68 & 136.6 \\
\hline \multirow[t]{6}{*}{ III } & Population (Million) & 1.60 & 7.09 \\
\hline & Population increasing rate (\%) & zero & 4.43 \\
\hline & Water consumption ( L Capita $^{-1}$ day $^{-1}$ ) & 165 & 110 \\
\hline & Domestic abstraction $\left(\mathrm{MCM} \mathrm{yr}^{-1}\right)$ & 95 & 208.52 \\
\hline & Agriculture abstraction $\left(\mathrm{MCM} \mathrm{yr}^{-1}\right)$ & 80 & 80 \\
\hline & Total abstraction (MCM yr ${ }^{-1}$ ) & 175 & 288.52 \\
\hline
\end{tabular}

The GCA is an extremely interesting case study of real sea bed slope. The results of GCA simulations permit a deeper discussion and validation of the theoretical assessments realised with the Henry's problem approach.

\subsubsection{Effect of physical subsurface barriers}


The physical subsurface barriers is installed at $3000 \mathrm{~m}$ from shoreline with hydraulic conductivity of $1 \times 10^{-5} \mathrm{~m}$ per day, the bottom of cut-off wall level is (-101.00) from mean sea level and $(+45.00)$ from ground surface (see Figure 8a), while top subsurface dam is carried out at level at level $(-73.00)$ and the bottom at level (-176.00) (see Figure $8 \mathrm{~b}$ ). SUl reached $3035 \mathrm{~m}$ and $3002 \mathrm{~m}$ form shore line, the salt mass is reached $9999650,1.01537 \times 10^{7} \mathrm{~kg}$ for the two cases respectively as presented in Figure $9 \mathrm{a}$ and $9 \mathrm{~b}$.

\subsubsection{Effect of earth fill}

Figure $8 \mathrm{c}$ presents the land fill used for GCA. The land fill depth is ranged from level $(-9.30)$ to $(-20.70)$ from MSL with length $1200 \mathrm{~m}$ from shore line, the fill hydraulic conductivity is $0.10 \mathrm{~m}$ per day. SWI reached $5510 \mathrm{~m}$, as presented in Figure $9 \mathrm{c}$. The aquifer salt mass is reached $9116411 \mathrm{~kg}$.

\subsubsection{Effect of abstraction and recharge methods}

Abstraction well and recharge well to manage the SWI in the case of GCA were simulated. Three cases are considered: the first is recharge of treated wastewater, the second is abstraction of brackish water, the third is a combination of recharge and abstraction.

The total expected production from wastewater in Gaza strip will be reached $109.47 \mathrm{MCM} \mathrm{yr}^{-1}$ and the leakage is $21.89 \mathrm{MCM} \mathrm{yr}^{-1}$ so the total volume of wastewater out let will be $87.58 \mathrm{Mm}^{3} /$ year (Table 5). Production of treated wastewater increases gradually by an increment of $2 \mathrm{MCM} \mathrm{yr}^{-1}$ (Sirhan, 2013). The actual value of wastewater treatment could be assessed equal to $80 \mathrm{MCM} \mathrm{yr}^{-1}$ by 2050 . The excess quantity of untreated wastewater is disposed to the Mediterranean Sea; the volume is assessed equal to 31.90 and $7.58 \mathrm{MCM} \mathrm{yr}^{-1}$ by 2010 and 2050 respectively.

The recharge well was located at $6000 \mathrm{~m}$ from shore line with depth -60.00 form MSL.

SUl reached 3350 m with salt mass of 6028400 kg, as presented in Figure 8d.

The future desalination volume is expected to $129.74 \mathrm{MCM} \mathrm{yr}^{-1}$ by 2035 for long term (PWA, 2011). This modification was simulated using the same value by 2050 and installing abstraction wells from brackish water. The abstraction well was simulated at $3000 \mathrm{~m}$ from shore line with depth -160.00 from MSL.

SUI reached $2990 \mathrm{~m}$ with salt mass of $1.00089 \times 10^{7} \mathrm{~kg}$. Combining recharge and abstraction wells, SUI reached $2933 \mathrm{~m}$ with salt mass is $6413380 \mathrm{~kg}$ (See Figure 9d, 9e and 9f). 
Table 5

Quantity of produced of treated wastewater and desalination in 2010 and 2050 at Gaza Strip

\begin{tabular}{|c|c|c|c|}
\hline Year & Case & 2010 & 2050 \\
\hline \multirow[t]{3}{*}{ Wastewater } & Production (MCM $\left.\mathrm{yr}^{-1}\right)$ & 39.90 & 87.58 \\
\hline & Treatment $\left(\mathrm{MCM} \mathrm{yr}^{-1}\right)$ & 8 & 80 \\
\hline & Disposal to Mediterranean Sea $\left(\mathrm{MCM} \mathrm{yr}^{-1}\right)$ & 31.90 & 7.58 \\
\hline Desalination & 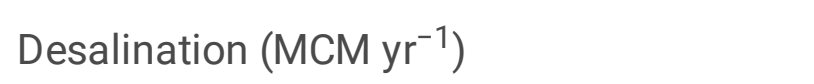 & 6 & 129,74 \\
\hline
\end{tabular}

In this scenario GCA was simulated adding check dam as presented in Figure $\mathbf{8 e}$. The head of dam is +7.00 AMSL and distance from 1400 to $1800 \mathrm{~m}$ from shore line.

The results of this scenario are presented in Figure 9g; SUI reached $4203 \mathrm{~m}$ from shore line with salt mass is $7918470 \mathrm{~kg}$. 
Table 5

Salt repulsion percentage for Gaza aquifer

\begin{tabular}{|c|c|c|c|c|c|}
\hline $\begin{array}{l}\text { Run } \\
\text { number }\end{array}$ & Case & Unit & Values & $\begin{array}{l}\text { Intrusion length for } \\
\text { Eqi-line } 35000(\mathrm{~m})\end{array}$ & $\begin{array}{l}\text { Salt } \\
\text { volume } \\
(\mathrm{kg})\end{array}$ \\
\hline 1 & base & - & - & 3177 & 5718820 \\
\hline \multirow[t]{4}{*}{2} & SLR & $\mathrm{cm}$ & 23.60 & 6281 & 10462100 \\
\hline & $\begin{array}{l}\text { Reduction in } \\
\text { precipitation }\end{array}$ & MCM $\mathrm{yr}^{-1}$ & 36.15 & & \\
\hline & Reduction in recharge & MCM $\mathrm{yr}^{-1}$ & 19.35 & & \\
\hline & Over pumping & MCM $\mathrm{yr}^{-1}$ & 288.52 & & \\
\hline 3 & Cut-off wall & depths (m) & 100 & 3035 & 9999650 \\
\hline 4 & Subsurface dam & depths (m) & 100 & 3002 & 10453700 \\
\hline 5 & Earth fill & $\begin{array}{l}\text { Permeability } \\
\left(\mathrm{m} \mathrm{day}^{-1}\right)\end{array}$ & 0.10 & 5510 & 9116411 \\
\hline 6 & $\begin{array}{l}\text { Recharge using treated } \\
\text { wastes water }\end{array}$ & $\begin{array}{l}\text { Rates } \\
\left(\mathrm{MCM} \mathrm{yr}^{-1}\right)\end{array}$ & 80 & 3350 & 6028400 \\
\hline 7 & $\begin{array}{l}\text { Abstraction from } \\
\text { brackish water }\end{array}$ & $\begin{array}{l}\text { Rates } \\
\left(\mathrm{MCM} \mathrm{yr}^{-1}\right)\end{array}$ & 129.74 & 2990 & 10008900 \\
\hline 8 & $\begin{array}{l}\text { Combine of recharge } \\
\text { and abstraction }\end{array}$ & $\begin{array}{l}\text { Rates } \\
\left(\mathrm{m}^{3} \text { day }^{-1}\right)\end{array}$ & $\begin{array}{l}80(\mathrm{R}) \\
\text { and } \\
129.74 \\
(\mathrm{~A})\end{array}$ & 2933 & 6413380 \\
\hline 9 & Check dam & Heads (m) & +7.00 & 4203 & 7918470 \\
\hline
\end{tabular}

\section{Conclusions}

Saltwater intrusion in coastal aquifers is a natural phenomenon which can cause groundwater quality degradation. This study aims to identify the impact of bed slopes for seaside (10:1), horizontal and land side (10:1) on SWI considering the possible impact of SLR and reduction in natural recharge, also investigate the effect of using different control methods. The study was carried out using SEAWAT for Henry problem and land side bed slope of Gaza aquifer, Palestine.

The land side slopes increase the SWI by $57.99 \%$ compare with 52.12 and $50.05 \%$ for horizontal and sea side bed slopes. SWI repulsion were reached $26.88,30.09$, and $28.66 \%$ for using cut-off wall and reached 
$10.38,12.45$ and $13.55 \%$ using subsurface dam while using land fill led to SWI repulsion of 15.92, 18.90, and $20.11 \%$ respectively. Also, applying the hydraulic methods of recharge of freshwater led to repulsion of $30.13,30.27$ and 30.57 while using the abstraction of brackish water to $7.64,6.97$ and $6.48 \%$, moreover combination of two cases led to $34.55,34.38$ and $34.41 \%$. The check dam led to SWI repulsion of $44,46.70$ and $43.82 \%$ for the three aquifer bed slopes of sea side, horizontal and land side.

\section{Declarations}

\section{Acknowledgment}

The authors are thankful to the Department of Water and Water Structures Engineering, Faculty of Engineering, Zagazig University, Zagazig 44519, Egypt, for constant support during the study.

\section{Funding}

(This study did not receive any funding)

\section{Conflicts of interest/Competing interests}

(The authors declare no conflict of interest.)

\section{Availability of data and material}

(Upon request)

\section{Code availability}

(Upon request)

\section{Authors' contributions:}

Ismail Abd-Elaty: Conceptualization, Software; Data curation; Writing, Maurizio Polemio, Reviewing and Editing Methodology, Original draft preparation, Supervision.

\section{Ethics approval}

(Not applicable)

Consent to participate

(Yes)

\section{Consent for publication}




\section{References}

1. Abd-Elaty I, Saleh OK, Ghanayem HM, Grischek T, Zelenakova M (2021a) Assessment of hydrological, geohydraulic and operational conditions at a riverbank filtration site at Embaba, Cairo using flow and transport modeling. J Hydrology: Reg Stud 37. https://doi.org/10.1016/j.ejrh.2021.100900

2. Abd-Elaty I, Kuriqi A (2021b) Sustainable Saltwater Intrusion Management in Coastal Aquifers under Climatic Changes for Humid and Hyper-Arid Regions. Ecol Eng 171. https://doi.org/10.1016/j.ecoleng.2021.106382

3. Abd-Elaty I, Javadi A, Abd-Elhamid H (2021c) " Management of saltwater intrusion in coastal aquifers using different wells systems: a case study of the Nile Delta aquifer in Egypt". Hydrogeol J. https://doi.org/10.1007/s10040-021-02344-w

4. Abd-Elaty I, Abd-Elhamid F, Qahman K (2020a) " Coastal Aquifer Protection from Saltwater Intrusion Using Abstraction of Brackish Water and Recharge of Treated Wastewater: Case Study of the Gaza Aquifer". J Hydrol Eng Issue 7(25). https://doi.org/10.1061/(ASCE)HE.1943-5584.0001927

5. Abd-Elhamid HF, Abd-Elaty I, Mohsen M, Sherif (2020b) "Effects of Aquifer Bed Slope and Sea Level on Saltwater Intrusion in Coastal Aquifers" Hydrology 7, no. 1: 5. https://doi.org/10.3390/hydrology7010005

6. Abd-Elaty I, Sallam G, Strafacec A, Scozzari A (2019a) " Effects of climate change on the design of subsurface drainage systems in coastal aquifers in arid/semi-arid regions: Case study of the Nile delta". Sci Total Environ J 672:283-295. https://doi.org/10.1016/j.scitotenv.2019.03.483

7. Abd-Elaty I, Hany FA, Nezhad M, M (2019b) Numerical analysis of physical barriers systems efficiency in controlling saltwater intrusion in coastal aquifers. Environ Sci Pollut Res. https://doi.org/10.1007/s11356-019-06725-3

8. Abualtayef M, Abdel Rahman G, Snounu I, Qahman K, Sirhan H, Seif A, K (2017) Evaluation of the effect of water management interventions on water level of Gaza coastal aquifer. Arab J Geosci 10:555

9. Abu Heen Z, And Muhsen S (2016) "Application of Vertical Electrical Sounding for Delineation of Sea Water Intrusion into the Freshwater Aquifer of Southern Governorates of Gaza Strip, Palestine", IUG Journal of Natural Studies Peer-reviewed Journal of Islamic University-Gaza, Vol 24, No 2, 2016, pp 07-20

10. Abd-Elhamid HF, Abd-Elaty I, Hussain MS (2020) Mitigation of seawater intrusion in coastal aquifers using coastal earth fill considering future sea level rise. Environ Sci Pollut Res 27:23234-23245. https://doi.org/10.1007/s11356-020-08891-1

11. Abd-Elhamid H, Abd-Elaty I (2017) Application of a new methodology (TRAD) to control seawater intrusion in the nile delta aquifer, Egypt, Solutions to Water Challenges in MENA Region Proceedings of the Regional Workshop, April 25-30, 2017 - Cairo, Egypt

12. Abd-Elhamid HF, Javadi A, Abdelaty I, Sherif M (2016) " Simulation of seawater intrusion in the Nile Delta aquifer under the conditions of climate change". Hydrol Res 47(6):1198-1210. 
https://doi.org/10.2166/nh.2016.157

13. Abd-Elhamid HF, Javadi AA (2008a) "Mathematical models to control saltwater intrusion in coastal aquifer", Proceeding of GeoCongress, New Orleans, Louisiana, USA

14. Abdoulhalik A, Ahmed A, Hamill GA (2017) A new physical barrier system for seawater intrusion control. J Hydrol 549:416-427

15. Agren J, Svensson R (2007) Postglacial Land Uplift Model and System Definition for the New Swedish Height System RG 2000. Gävle, Sweden, Lantmäteriet

16. Bear J, Cheng AH, Sorek S, Quazar D, Herrera I (1999) Seawater intrusion in coastal aquifers, concepts, methods and practices. Kluwer Academic publisher, Dordrecht, The Netherlands. ISBN 07923-5573-3

17. Baalousha $\mathrm{H}$ (2008) Analysis of nitrate occurrence and distribution in groundwater in the Gaza Strip using major ion chemistry. Global NEST J 10:337-349

18. Cheng J, Strobl RO, Yeh G, Lin H, Choi W (1998) "Modelling of 2D Density-Dependant Flow and Transport in the Subsurface",Journal of Hydrologic Engineering, Vol. (3), No. (4), PP.248-257

19. Church JA, Clark PU (2013) Sea Level Change. Climate Change 2013: The Physical Science Basis, Contribution of Working Group 1 to the Fifth Assessment Report of the Intergovernmental Panel on Climate Change. IPCC, Geneva, Switzerland

20. Fahs M, Koohbor B, Belfort B, Ataie-Ashtiani B, Simmons CT, Younes A, Ackerer P (2018) "A Generalized Semi-Analytical Solution for the Dispersive Henry Problem: Effect of Stratification and Anisotropy on Seawater Intrusion" Water 10, no. 2: 230. https://doi.org/10.3390/w10020230

21. Frind EO (1982) "Simulation of long-term transient density-dependent transport in groundwater". Water Resour Res 5(2):73-88

22. Guo W, Langevin CD (2002) User's Guide to SEAWAT: A Computer Program for Simulation of ThreeDimensional Variable-Density Groundwater Flow, US Geological Survey Techniques of Water Resources Investigations 6-A7. US Geological Survey, Tallahassee, Florida

23. Guo H, Jiao JJ (2007) Impact of Coastal Land Reclamation on Ground Water Level and the Sea Water Interface. Ground Water 45(3):362-367

24. Guo H, Jiao JJ (2009) Coastal Groundwater System Changes in Response to Large-scale Land Reclamation. Nova Science Publishers,Inc, New York

25. Ghyben BW (1889) "Nota in Verband Met de Voorgenomen put Boring Nabij Amsterdam". Tydscrift Van Het Koninkyky Institute Van Ingenieurs, the Hahue, the Netherlands, p 21

26. Harbaugh AW, Banta ER, Hill MC, McDonald MG (2000) MODFLOW-2000, the U.S. Geological Survey Modular Ground-Water Model-User guide to modularization concepts and the ground-water flow process: U.S. Geological Survey Open-File Report 00-92, 121 p

27. Herzberg A (1901) "Die wasserversorgung Einnger Nordsecbader", Journal Gasbeleuchtung U. Wasservesurg, Jahrg 44, Munich, Germany, PP.815-819 
28. Henry HR (1964) Effect of Dispersion on Salt Encroachment in Coastal Aquifers, U.S. Geol. Surv., Water-Supply Pap. 1613-C: 70-84

29. IPCC (2021) The IPCC has finalized the first part of the Sixth Assessment Report, Climate Change 2021: The Physical Science Basis, the Working Group I contribution to the Sixth Assessment Report. It was finalized on 6 August 2021 during the 14th Session of Working Group I and 54th Session of the IPCC

30. IPCC (2014) Climate Change 2014: Synthesis Report. Contribution of Working Groups I, II and III to the Fifth Assessment Report of the Intergovernmental Panel on Climate Change [Core Writing Team, R.K. Pachauri and L.A. Meyer (eds.)]. IPCC, Geneva, Switzerland, 151 pp

31. IPCC (2007) An Assessment of the Intergovernmental Panel on Climate Change, Adopted section by section at IPCC Plenary XXVII (Valencia, Spain, 12-17 November 2007), represents the formally agreed statement of the IPCC concerning key findings and uncertainties contained in the Working Group contributions to the Fourth Assessment Report

32. Climate Change 2001: Impacts, Adaptations, and Vulnerability: contribution of working group II to the third assessment report of the Intergovernmental Panel on Climate Change. McCarthy, IPCC, Canziani JJ, Leary OF, Dokken NA, White K (2001) S. Cambridge University Press, Cambridge, UK and New York, NY, USA

33. Intera EC (1979) " Revision of the Documentation for a Model for Calculating effects of Liquid Waste Disposal in Deep Saline Aquifers. U.S. Geol. Surv.Water Res.Publ:79-96 72p

34. Javadi A, Hussain M, Sherif M, Farmani R (2015) "Multi-objective optimization of different management scenarios to control seawater intrusion in coastal aquifers". Water Resour Manage 29(6):1843-1857

35. Mahmoodzadeh D, andM. Karamouz (2019) Seawater intrusion in hetero-geneous coastal aquifers under flooding events. J Hydrol 568(Jan):1118-1130. https://doi.org/10.1016/j.jhydrol.2018.11.012

36. McDonald RI, Green P, Balk D, Fekete BM, Revenga C, Todd M, Montgomery M (2011) Urban Growth, Climate Change, and Freshwater Availability. Proceedings of the National Academy of Sciences 108, 6312-6317, doi:10.1073/pnas.1011615108

37. Metacalf and Eddy (2009) Geophysical survey in the Gaza governorate. Blackhawk geometrics project number 2009. Gaza Strip

38. Mercado A (1968) A hydrological survey of ground water in the Gaza Strip (in Hebrew), Rep. 1968, Tahal Co. Ltd., Tel Aviv, Israel

39. Melloul A, Collin M (1994) The hydrological malaise of the Gaza Strip. Isr Earth Sci J 43:105-116

40. Miao T, Lu W, Lin J, Guo J, Fan Y (2019) Simulation of seawater intrusion and optimization of cutoff wall schemes based on surrogate model. Hum Ecol Risk Assessment: Int J 25:297-313

41. Palestine Palestinian Water Authority, PWA (2015) “Water resources status summary report/Gaza Strip". PWA, Palestine

42. Palestinian Water Authority, PWA (2014) Environmental and social impact assessment and environmental and social management plan for Gaza water supply and sewage systems 
improvement project. PWA, Palestine

43. Palestinian Water Authority (PWA) (2013) Archived data. PWA, Gaza

44. Palestinian W, Authority PWA (2012) "Annual status report on water resources, water supply, and wastewater in the occupied state of Palestine\&\#8221

45. Palestinian W, Authority PWA (2011) The Gaza Emergency Technical Assistance Programme (GETAP) on water supply to the Gaza Strip, the Comparative Study of Options for an Additional Supply of Water for the Gaza Strip (CSO-G), the updated final report. PWA, Palestine

46. Palestinian W, Authority PWA (2001) "Hydrogeological report for the Gaza strip", Technical report, Volume 2, Palestinian Water Authority (PWA), Palestine, 67 pp

47. PCBS (2000) Population, housing and establishment census 1997. Palestinian National Authority, Palestinian Central Bureau of Statistics (PCBS), Ramallah,. 19 pp

48. PCBS (2000) Population, housing and establishment census 1997. Palestinian National Authority, Palestinian Central Bureau of Statistics (PCBS), Ramallah,. 19 pp

49. PCBS (2015c) Palestinians Population Status in the Palestine, 2015. Ramallah - Palestine. Retrieved from http://www.pcbs.gov.ps/Downloads/book2135.pdf

50. Polemio M, Zuffianò LE (2020) Review of Utilization Management of Groundwater at Risk of Salinization. J Water Resour Plan Manag 146(9):20. doi: 10.1061/(ASCE)WR.1943-5452.0001278

51. Qahman K, Larabi A (2006) "Evaluation and numerical modeling of seawater intrusion in the Gaza aquifer (Palestine) ". Hydrogeol J 14(5):713-728

52. Qahman Kh, Thesis (2004) UNIVERSITE MOHAMED V - AGDAL, Morocco, 181 pp

53. Rastogi AK, Choi GW, Ukarande SK (2004) "Diffused interface model to prevent ingress of seawater in multi-layer coastal aquifers". J Special Hydrology 4(2):1-31

54. Roger LJ, Kazuro M, Kei N (2010) Effects of artificial recharge and flow barrier on seawater intrusion. Ground Water

55. Roger LJ, Kazuro M, Kei N (2009) Laboratory-scale saltwater behavior due to subsurface cutoff wall. J Hydrol 377:227-236

56. Sarsak RF (2011) Numerical Simulation of Seawater Intrusion in Response to Climate Change Impacts in North Gaza Coastal Aquifer Using SEAWAT", MSc, Faculty of Graduate Studies. at AnNajah National University, Nablus, Palestine

57. Sirhan H, Koch M (2013) Numerical modeling of the effects of artificial recharge on hydraulic heads in constant-density ground water flow to manage the Gaza Aquifer, Coastal Palestine, South. In: Proceeding 6th International Conference on Water Resources and Environment Research, 114-147. doi:10.5675/ICWRER

58. Ghabayen, Salha AA (2013) " Crop Water Requirements (CWR) Estimation in Gaza Strip Using ArcMap-GIS Model Builder" International Journal of Emerging Technology and Advanced Engineering, 3 (10)

59. SWIMED project (2002) Sustainable Water Management in Mediterranean coastal aquifers 
60. Shomar B, Abu Fakher S, Yahya A (2010) "Assessment of Groundwater Quality in the Gaza Strip, Palestine Using GIS Mapping",Journal of Water Resource and Protection, Vol. (2), PP93-104

61. Shatat M, Arakelyan K, Shatat O, Forster T, Mushtaha A, Riffat S (2018) Low Volume Water Desalination in the Gaza Strip - Al Salam Small Scale RO Water Desalination Plant Case Study. Future Cities and Environment 4(1):11. DOl:http://doi.org/10.5334/fce.40

62. SVCHEM (2018) SoilVision Systems Ltd", Saskatoon, Saskatchewan, Canada

63. Simpson MJ, Clement TB (2004) Improving the worthiness of the Henry problem as a benchmark for density-dependent groundwater flow models. Water Resour Res 40(1):1-11

64. Voss Cl, Souza WR (1987) Variable density flow and solute transport simulation of regional aquifers containing a narrow fresh-watersaltwater transition zone. Water Resour Res 23:1851-1866

65. Wada Y, Flörke M, Hanasaki N, Eisner S, Fischer G, Tramberend S, Satoh Y, van Vliet MTH, Yillia P, Ringler $C$ et al (2016) Modeling Global Water Use for the 21st Century: The Water Futures and Solutions (WFaS) Initiative and Its Approaches. Geosci Model Dev 9:175-222. doi:10.5194/gmd-9175-2016

66. Zheng C, Wang PP (1999) MT3DMS, A modular Three-Dimensional Multi Species Transport Model for Simulation of Advection, Dispersion and Chemical Reactions of Contaminants in Groundwater Systems: Documentation and user's guide. U.S. Army Engineer Research and Development Center Contract Report SERDP-99-1, Vicksburg, MS. 202

67. Zhao M, Zhang G, Wang P, Du X, Zhang X (2020) An accurate frequency-domain model for seismic responses of breakwater-seawater-seabed-bedrock system. Ocean Eng 197:106843

\section{Tables}

Table 3 is available in the Supplementary Files section.

\section{Figures}




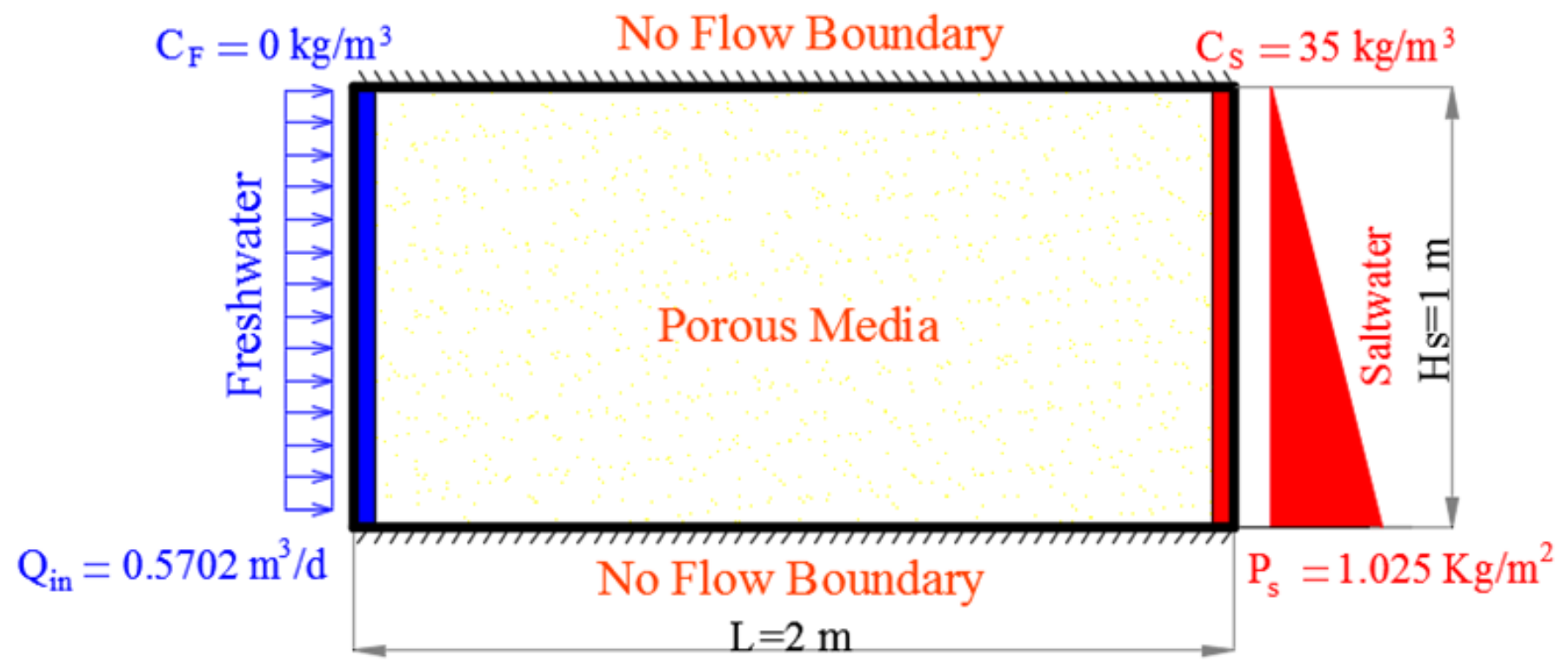

(a)

Sharn Interface Solution

Figure 1

Henry's problem for (a) Definition sketch and boundary conditions and (b) SWI results for SEAWAT results and other codes

Figure 2 
Gaza Strip Location and hydrogeological

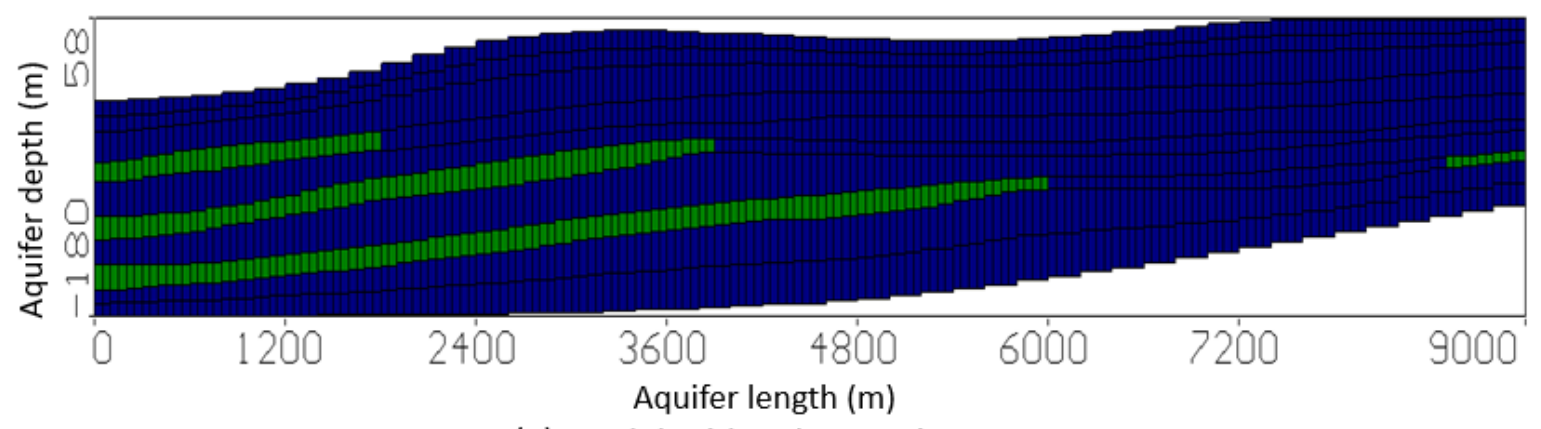

(a) Model grid and extension

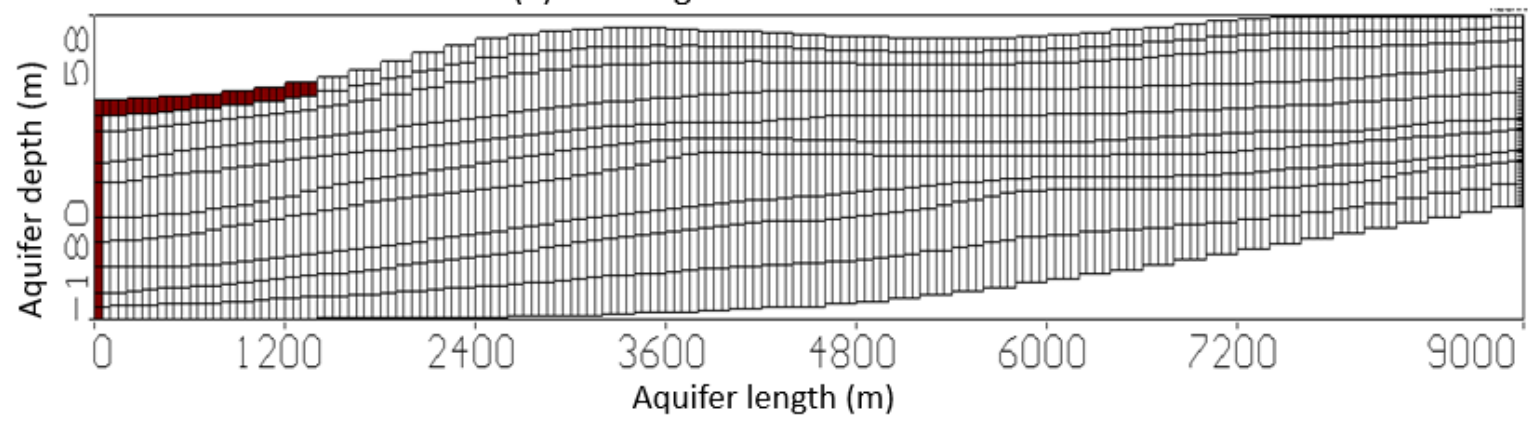

(b) Head

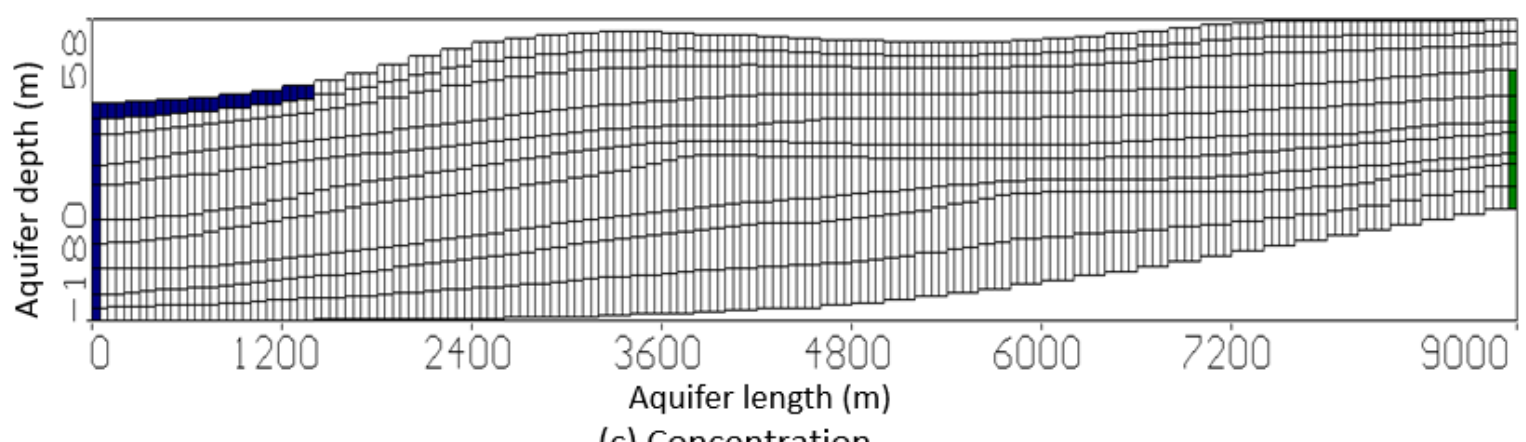

(c) Concentration

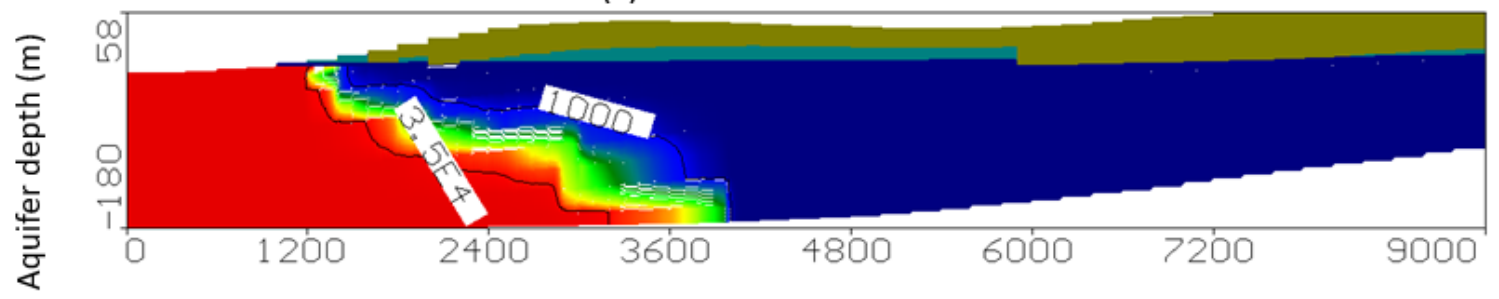

Aquifer length (m)

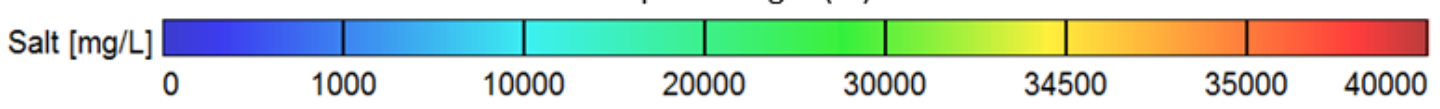

(d) TDS distribution in Gaza aquifer by SEAWAT for the current study

\section{Figure 3}

Vertical section of Gaza aquifer for with boundary conditions and SEAWAT results 
(a)

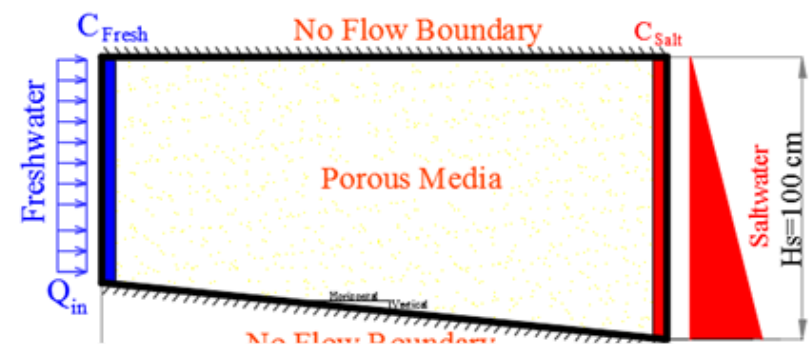

(b)

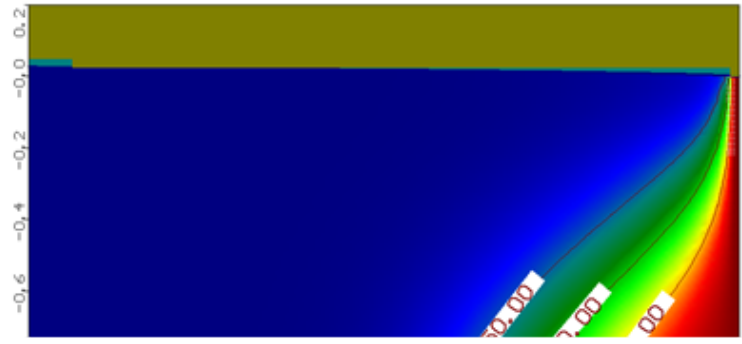

Figure 4

Schematic sketch and equi-concentration line 17,500 ppm under different slopes of Henry's problem 


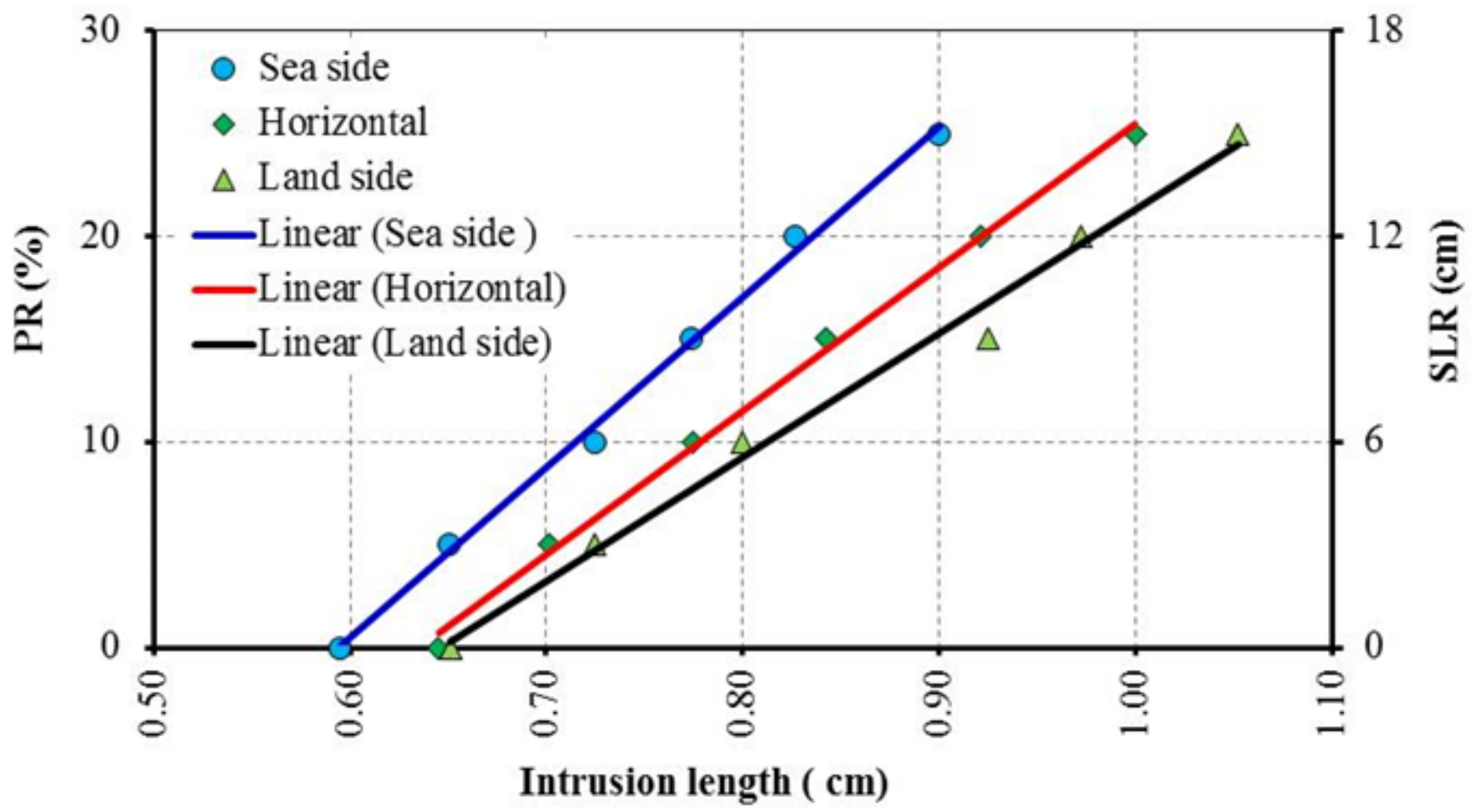

Figure 5

SWI results in the case of SLR and recharge reduction. 

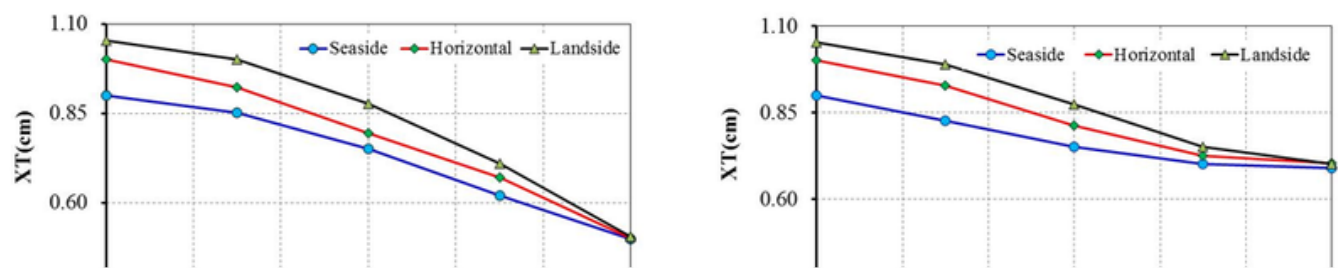

Figure 6

Relationship between SWI and management techniques for different bed slopes of Henrys problem 


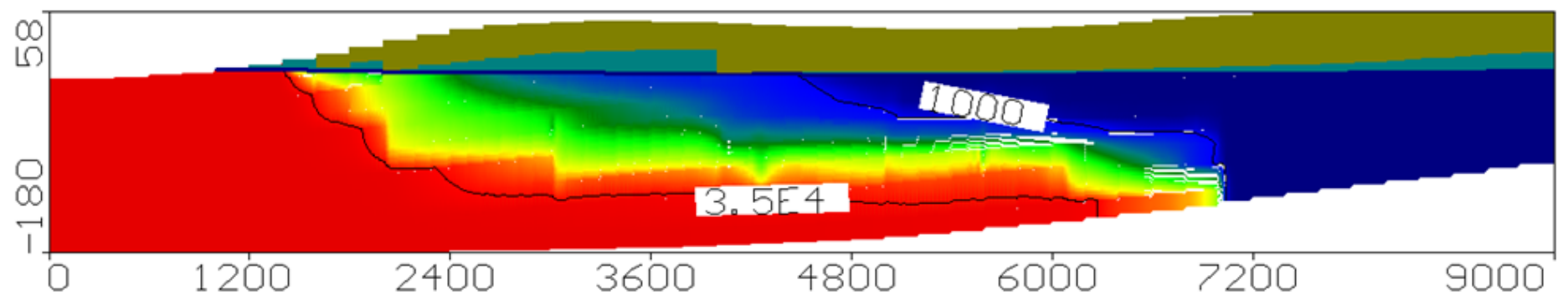

\section{Figure 7}

Equi-concentration line 17,500 ppm under different conditions in Gaza aquifer

\section{Figure 8}

Installing different management techniques for the GCA (a real case of sea bed slope) 


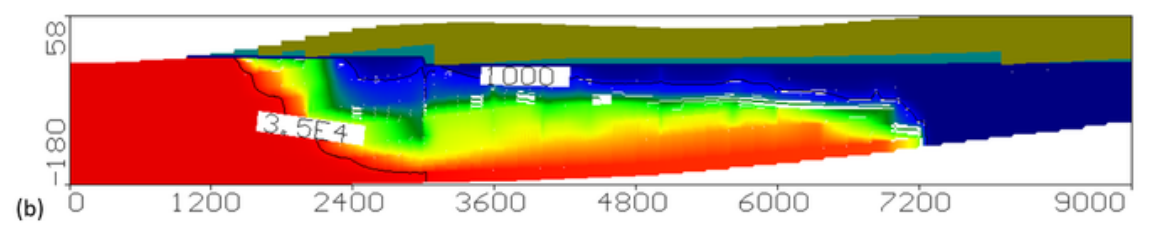

(a) TDS distribution using cutoff wall

\section{Figure 9}

Salinity distribution using different management techniques for sea bed slopes of Gaza aquifer

\section{Supplementary Files}

This is a list of supplementary files associated with this preprint. Click to download. 
- Table3.docx

- GraphicalAbstract.docx

- Highlights.docx 